\title{
Ronggeng: Cultural Artifact and Its Representation in Indonesian Film
}

\author{
Yulianeta \\ Universitas Pendidikan Indonesia \\ yaneta@upi.edu
}

\begin{abstract}
Ronggeng is a cultural artifact that is very popular in the life of Indonesian people, especially in Java. In a historical context, ronggeng which is on the concept was originally viewed as a sacred culture in its development into a profane culture. The reception of ronggeng is not only uttered orally, but also in literature and film. This study aims to describe ronggeng as a cultural artifact and its representation in the film Nyi Ronggeng (1969), Darah dan Mahkota Ronggeng (1983), and Sang Penari (2011). The method used in this research is descriptive analysis method representation theory of Stuart Hall, to see how the image of ronggeng is represented in three films. Although there are similarities, but the three films proved different levels of reception about ronggeng. It illustrates the development of people's thoughts on ronggeng that live within them. Ronggeng as a tradition changes according to the development of community thinking. Ronggeng as a cultural artifact is the manifestation of the ability of local communities to respond and adapt to the environment actively. Similarly, what is represented in the three films about ronggeng is a mirror of the society where the work was born.
\end{abstract}

Keywords: Indonesian film, reception, representation, ronggeng

\section{INTRODUCTION}

Ronggeng is a popular art in Indonesian society. This is a traditional art in the form of dances growing well in agrarian society. Ronggeng usually becomes a medium for farmers to hold a thanksgiving ritual for the harvest gained. Time to time, this art is not only utilized for sacred rituals, but also develops to be a profane art [1], [2].

Besides being well-known as ronggeng, this art is also called gandrung, lengger, taledhek, tandak, and so forth. Ronggeng Melayu is developing in Sumatra and Ronggeng Betawi is spreading in Jakarta. In Subang and Sumedang, West Java, people call it Bangreng. Meanwhile, in Banyuwangi, Bali, and Lombok, its famous name is Gandrung. Lengger is another name for it in Purwokerto, Wonosobo, and Magelang. While the name taledhek, ledhek, joged, ronggeng, and tandak are used to call female dancers in a ronggeng show or tayub in several regions of Central Java and East Java. The last, people in West Java call them sindhen or ronggeng. This art spreads almost in all regions of Java Island [3].

Ronggeng word comes from Javanese language, which means tandak or female dancers accompanied by gamelan (Javanese traditional orchestra). Referring to the definition, women become the key of the art. In the Ensiklopedi Tari Indonesia Seri P-T, ronggeng is classified into couple entertainment dances performed by a woman and a man. On its shows, a female ronggeng dancer usually asks a male dancer by throwing her shawl to the man to go up to the stage and dance together with her [4]. Once the dance is finished, the male dancer should give her money.

Since women become the core of the dance and men are the main party to enjoy it, the negative image of ronggeng dancers appears. As highlighted by Soeharto and Sooi that in a society, a ronggeng's life is identical with prostitutes who frequently sell themselves to the men who desire them. Although not all people think the same, but people's appraisal towards ronggeng particularly female dancers decreases [5], [6].

It is an unavoidable thing that the negative image of ronggeng is possibly affected by the fact that most of ronggeng dancers possess plump bodies. To be a ronggeng dancer, a woman should have been dancing at the age of eight (usually called lengger) [7]. [8]. The requirements of changing a lengger into a ronggeng are frequently connected to a belief of indhang's presence, a spirit possessing a ronggeng dancer. The myth of a ronggeng dancer's perfect beauty after being possessed by indhang indicates how a ronggeng dancer image is, that they should not only be plump but also beautiful. This is the reason why the procession to be a ronggeng dancer is considered very sacred.

This image is then depicted in a variety of literary works either spoken or written, or visual (films). Pratista mentions that films can be defined as a tool to convey various messages to people through a story as the medium. Films are not only visual media offering entertainment. More than that, films are media to transfer ideas to audiences [9]. Films are described as mass communication media as well. Like literary works, films are expressed as cultural documents representing society culture per se.

Three of the films concerning on ronggeng phenomenon is Nyi Ronggeng (1969), Darah dan 
Mahkota Ronggeng (1983), and Sang Penari (2011). Therefore, the present research is intended to analyze how a ronggeng image is depicted in three films.

\section{METHOD}

The present research employed an analytical descriptive research method by focusing the analysis on textual analysis of Nyi Ronggeng (1969), Darah dan Mahkota Ronggeng (1983), and Sang Penari (2011). The representation theory from Stuart Hall was applied to read how the ronggeng image and its dancers were presented in the films.

Representation is viewed as an accurate illustration of a reality. Hall defines representation as a critical practice in producing cultures. The process is divided into two, which are 'mental' and 'language' representation. The 'mental' representation connects to abstract thing in mind while 'language' representation relates to a process of constructing meaning. The process is sensed as how a world is reconstructed socially to and by us in a certain meaning [10].

\section{RESULT}

Nji Ronggeng takes a popular film genre (melodrama) and uses it as a framework for the representation of a traditional folk dance and its social context. The film, set in West Java in the 1930s, draws extensively upon local folk traditions sometimes modifying or amplifying them for purposes of the plot, which centers on the rivalry between two sons of local village heads. Both seek the hand of a ronggeng dancer who holds a disadvantaged social position, one of the earliest feature films that are made in this color in Indonesia.

Nji Ronggeng film was directed by Alam Surawidjaya. The film was set in villages around Sumedang, West Java. It tells about Nji Sari (a ronggeng dancer, played by Chitra Dewi) dancing in front of a group of villagers. The dance is performed as a thanksgiving ritual for the abundant blessings of the harvest. Ronggeng is a form of slametan procession (thanks to the goddess of rice, Dewi Sri, for a successful harvest). It is told that $\mathrm{Nji}$ Sari is loved by Dadang (Dicky Zulkarnaen), the eldest child of Tua Kampung Cijulang, who wants to take the position of a lurah. On the other hand, Ohim (Sandy Suwardi Hassan), the eldest child of Kampung Cigugur, is very desperate with Sari. Moreover, he almost feels embarrassed on the ronggeng stage, because he does not manage to conquer Sari by holding her hair bun as required. Meanwhile, Dadang's father is angry at Dadang's relationship with Sari, because it can affect his ambition to become a lurah. People also do not like it, especially the news that their relationship is deliberately spread by their party opponent, Tua Kampung Cigugur. Dadang does not care about that. This young man is hardworking and polite. $\mathrm{He}$ is very different from Ohim who is boastful and fond of women. He is more curious about Sari, because Sari does not seem like an ordinary ronggeng that men can easily buy, just like his friends do. The trauma of her mother, a ronggeng, too, who died because of being contested by men, formed Sari's attitude. The peak of the competition occurred in the people's party. In all games, Cigugur village was lost. Then, Ohim challenged others to play ujungan. This time, he won, until Dadang, who defeated him, came. Ohim still has not accepted it, until the bloodshed happened. Sari came to mediate and blamed those who craving for the power. The film tries to convey a message that not all ronggeng are the same. It intends to show Sundanese customs and arts. It also successfully brings out eroticism and sensuality of ronggeng.

This is in accordance with Alkema's statement that ronggeng dance is from shaman dance which is a dance performed by female priests to connect the inside world to the outside one, the world of ancestor spirit. Then, this dance was performed when conducting a religious ritual. Ronggeng is a sacrificial ritual for the fertility of agriculture. It was believed to posses magic-simpatetic power and it has influence on the ritual. By performing cleansing ritual for a village, the officers of villages invite the residents to join in dance in a field rice hoping that plants can grow well and be free from pest and any danger. Related to fertility ritual, Highwater reveals that dance may induce the miracle [11].

At the same way, Soedarsono also shows that in an agrarian culture, the fertility of the soil is farmers' only hope. They believe that the fertility of the soil cannot be gained by increasing new agricultural systems only, but it is also important to do some efforts by transforming magical power [12], [13].

Darah dan Mahkota Ronggeng is a film adapted from Ronggeng Dukuh Paruk, a novel by Ahmad Tohari (1982). Directed by Yazman Yazid, the film was released on the big screen produced by Gramedia Films in 1983, one year after the novel Ronggeng Dukuh Paruk was first published.

The main character, Srintil (Enny Beatrice) is considered to have the blood of ronggeng that has not been owned by a village. The villagers earn a living from ronggeng. This villagers' belief was inherited from the village pioneers who lived in a barren and arid region. Ronggeng is considered as the life savior for both material and spiritual in the village.

After being old enough, Srintil has to undergo the main ceremony bukak klambu, that is giving her virginity to anyone who can pay the highest. Interestingly, whoever can give a gold bar to the ronggeng shaman, has the right to take Srintil's virginity. However, Srintil has already given hers to Rasus because she loves him. It is clear that Srintil's attitude was ambiguous between obeying the culture or avoiding it. Srintil consciously chooses to be a ronggeng as well as a prostitute for Dukuh Paruk will be empty and gloomy without ronggeng.

Srintil as a ronggeng is associated also with the soil fertility. The climax of ronggeng is when a woman and a man dance together called ngibing. Generally, nobles will have the first opportunity to ngibing with ronggeng 
which is called bedah bumi. This ritual is translated as bedah bumi for the purpose of prosperity of the people in the earth. This kind of relation of ronggeng is believed to influence the fertility of the soul. However, ronggeng that has ritual function is now becoming a secular show. As shown by the requirements of being a ronggeng is a ritual called bukak klambu and after that ronggeng belongs to public.

The ronggeng in Sang Penari film was illustrated by figuring Surti and Srintil. Surti, played by Happy Salma, only appeared in several scenes in the opening. It is narrated that Surti passes away because of a poisonous bongkrek tempeh tragedy which also kills some villagers of Dukuh Paruk. Through Surti, Srintil, the character played by Prisia Nasution, is then interested in ronggeng.

Little Srintil once watched a ronggeng show in Dukuh Paruk when the ronggeng dancer was Surti. From her interest, Srintil became fond of dancing and singing. When she was five years old, she had shown her dancing and singing talent. Moreover, Sakarya (Srintil's grandfather), played by Landung Simatupang, assured that Srintil's talent was not just a talent, but was also possessed by indhang.

Growing to be a beautiful and plump girl, Srintil is pointed as a Dukuh Paruk ronggeng with the assistance of a ronggeng shaman named Kartaredja, played by Slamet Rahardjo, and his wife, Nyai Kartaredja, played by Dewi Irawan. Being a ronggeng was Srintil's dream since she was little. By being a ronggeng, she does not only pursuit her dream, but also devotes herself to Dukuh Paruk and Eyang Sacamanggala, the ancestor believed by the people to protect the village.

Within a ronggeng's soul, body sensuality becomes a certain pride in attracting people to come and see a ronggeng dance. Sensuality is emphasized by Javanese context that believes in the presence of indhang spirit. Its presence is trusted to be able to give more attraction power for a ronggeng dancer, which cannot be obtained by everybody but by a ronggeng dancer.

The ronggeng of the film was described as a beautiful woman, having a plump body and white skin. Besides the requirement of having a ronggeng's aura or being possessed by ronggeng indhang, only good looking women can be ronggeng dancers.

Ronggeng is a collective possession, thus a ronggeng dancer belongs to a society. At this level, a ronggeng dancer is the goddess praised by the belief that a ronggeng brings beneficence. Ronggeng is also represented as a culture of low level people which is still close to animism and dynamism faith. At the end, the ronggeng art in the film leaves its cult, and just becomes the profane art which time to time is then left behind.

\section{CONCLUSION}

From the discussion, it can be drawn a conclusion that a ronggeng has particular beauty and sacred values. Ronggeng was considered as a sacred ritual and it becomes a profane art performance as reppresented in Indonesian films. Ronggeng or tayub as a cultural artifact in other regions may have different forms and values. It will be based on the ability of society adapting it to its environment. What has been represented in Indonesian films is the reflection of society's reception where the art work is produced.

\section{REFERENCES}

[1] Henry, S., "Ronggeng and Desire". Erotic Triangles : Sundanese Dance and Masculinity in West Java". Chicago: University of Chicago Press, 2010.

[2] Yulianeta, "Ronggeng: Cultural Artifacts and its Representation in Indonesian's Fiction". Leksika Journal of Language, Literature, and Language Teaching. Vol.7, No.2, 2013.

[3] Raffles, T. S., The History of Java. Vol 1, London and New York: Oxford University Press, 1965.

[4] Depdikbud, Ensiklopedi Tari Indonesia Seri P-T, Jakarta: Depdikbud, 1986.

[5] Soeharto B., Pertunjukan dan Ritus Kesuburan, Bandung: Masyarakat Seni Pertunjukan Indonesia, 1999.

[6] Sooi B. T., "From Folk to National Popular Music: Recreating Ronggeng in Malaysia". The Journal of musicological research. Volume: 24 Issue: 3-4, 2005, Page: 287-307. DOI: $10.1080 / 01411890500234054$.

[7] Geertz, C., The Religion of Java, Chicago and London: The University of Chicago Press, 1976.

[8] Koentjaraningrat, Kebudayaan Jawa, Jakarta: Balai Pustaka, 1989.

[9] Pratista, H., Memahami Film. Yogyakarta: Homerian Pustaka, 2008.

[10] Hall, S., Representation: Cultural Representation and Signifying Practices. London: Sage Publication, 1997.

[11] Surur, M., "Perempuan Tayub: Nasibmu di Sana, Nasibmu di Sini" dalam Srintil No. 2, 2003.

[12] Higwater, J., Dance: Ritual of Experience. Ed 3. New York: The Native Land Foundation, 1992.

[13] Soedarsono, R.M., "Tayub di Akhir Abad ke-20" dalam Soedarso, Sp., ed. Beberapa Catatan Tentang Perkembangan Kesenian Kita, Yogyakarta: BP ISI, 1991. 